\title{
Geografin
} Malavsian Ioumal of Society and Space

\section{Trust motivates funders to participate in Shari'ah crowdfunding}

\author{
Shifa Mohd Nor ${ }^{1,2}$, Noor Azuan Hashim ${ }^{3}$ \\ ${ }^{1}$ Centre for Governance Resilience and Accountability Studies, \\ Faculty of Economy and Management, Universiti Kebangsaan Malaysia \\ ${ }^{2}$ Institute of Islam Hadhari, Universiti Kebangsaan Malaysia \\ ${ }^{3}$ Centre for Value Creation and Human Well-being Studies, \\ Faculty of Economy and Management, Universiti Kebangsaan Malaysia \\ Correspondence: Noor Azuan Hashim (email: azuan@ukm.edu.my)
}

Received: 01 March 2020; Accepted: 15 May 2020; Published: 30 May 2020

\begin{abstract}
The fourth industrial revolution has influenced many sector including Islamic Finance. The digital revolution has changed the traditional crowdfunding through the usage of technology with smart applications on mobile phones and websites. Among the advantage of crowdfunding is its accessibility, fast transaction, security, transparency, traceability and many more. Through crowdfunding platforms, financial inclusion groups could be reached. Hence, the demand for Shari'ah crowdfunding increases to fulfil the Muslims developmental needs in providing for projects that are compliant according to Shari'ah. Shari'ah crowdfunding platform such as Shekra, Yomken, Ethiscrowd, Waqfworld, KapitalBoost and many more attempts to realize the needs of Muslim society. These activities utilize the financial technology (FinTech) approach via social media or smartphone apps. Although FinTech is widely used nowadays, there is an issue of trust from the investors in gaining their interest to invest in Shari'ah crowdfunding projects since it is virtual. Hence, this study explores the possibility of funder's motivation to invest in crowdfunding projects from the perspective of trust. This conceptual study highlights the element of trust from three elements which are calculus trust, relationship trust and religiosity (Islam). For future research, the study on trust from a social capital perspective would add value in contributing to the development of digital economy.
\end{abstract}

Keywords: crowdfunding, calculus trust, fintech, relationship trust, shari'ah, trust

\section{Introduction}

Financial technology (FinTech) has become the new agenda in supporting the fourth industrial revolution. Every financial industry is hooking up with new technology in providing the best products and services for their stakeholders especially customers. Thus, crowdfunding became a new agenda supporting the sharing economy in providing for the society's needs. Sharing economy is when the community shares their belongings or services 
with other individuals for a cost or for free via the internet. Crowdfunding occurs when a fundraiser seeks for funding to fulfil their project interest. There are two definition of crowdfunding; first, raising small amounts of money from a large number of people (Schwienbacher \& Larralde, 2010; Ordanini et al., 2011); second, the fundraising and financial transactions take place via the internet (Bellaflemme, 2013; Gierczak et al., 2016). According to World Bank (2013), crowdfunding is an internet-enabled way for fundraiser (business, NGO, society) to raise small amount of financial assistance in the form of either donations or investments from multiple individuals. These fundraising is done through networking from the society. The special characteristic that captures the stakeholders' interest on the usage of crowdfunding are many such as accessibility, fast transaction, security, traceability and also transparency. These characteristics are factors that contributes towards efficiency.

FinTech has influenced the traditional crowdfunding through the use of internet and smartphones apps. Crowdfunding platforms has gain a large sum of capital funds for various purposes such as social initiatives, entrepreneurship and many more. Awareness on this issue emerged for Islamic crowdfunding or also known as Shari'ah-based crowdfunding to use the same medium. Shari'ah crowdfunding platforms began to cater for the Muslims developmental needs in many aspects such as community development, entrepreneurship and education. Malaysia has achieved one of the highest levels of financial inclusion among Southeast Asia countries, as government establish policies and encouragement in expansion of financial access through digital technology, including the Islamic banking industry. Financial inclusion agenda is to ensure no one is left behind in accessing the formal financial system (Othman, 2015). This is evident when Malaysia becomes one of the first countries in Southeast Asia to give regulatory approval for equity crowdfunding, hence the number of crowdfunding platforms in Malaysia is rising (Mohd Thas Thaker et al., 2018). Mostly in Malaysia the motivation to contribute in crowdfunding is due to non-monetary motive and the expectation of social return. Nonetheless, the awareness and participation of crowdfunding in Malaysia is still relatively low (Shofiyyah et al., 2019).

Although the rapid innovation in crowdfunding provides ease and usefulness to each relevant parties, the issue of trust became a debate. The traditional Shari'ah crowdfunding which is associated with religious institutions has provide trust and security towards the crowdfunder as it is done offline. This practice embrace the humanistic approach by creating a trustworthy ambience through live experience in physical and emotional presence. Therefore, the presence of investor and fundraiser at the same place creates trust and binding contract through communication and relationship. With the escalating crowdfunding platform virtually, there are slight of distrust among investors towards funding a project or business (Gerber \& Hui, 2013). This situation occurs due to vague experience and lack of knowledge on the wellbeing and management of the fund, thus transparency and governance of the crowdfunding project is important to gain trust from every stakeholder. Hence, this study attempts to explore behavior of crowdfunders from the perspective of trust to invest in Shari'ah-based crowdfunding projects.

This is a conceptual paper that employs content analysis through library research. Secondary data are gathered and analyzed from journals, books and monographs. Therefore, the organization of the paper is as following. The next section will provide on review of literature regarding to the description of Shari'ah crowdfunding and the value of trust. Then, a conceptual framework is built and discussed to understand the elements of trust that influence the behavior of funders. Conclusion is offered in the final stage to recap the overall objective of this research. 


\section{Literature review}

\section{Shari'ah crowdfunding}

Islamic crowdfunding or relatively known as Shari'ah-based crowdfunding has become a potential financial assistance for entrepreneurial development. Crowdfunding is conceptualised as "Shari'ah compliance" once it conforms to Shari'ah law (Islamic law) that promotes profit-and-loss sharing and; ethical and social responsible investment. The Shar'iah prohibits any transaction associated to riba' (interest), gharar (uncertainty), maysir (gambling) and all unethical and dangerous industries i.e. alcohol, pork, drug and armory. While most crowdfunding categories fit into these principles of Islamic finance, loan-based crowdfunding requires adaptation to comply with Shari'ah compliant (IFSB, 2017; Marzban et al., 2014; Taha \& Macias, 2014). The crowdfunding activities are an alternative financial access to encourage entrepreneurship and social activities, which comes from the awareness and sense of responsibility of the society.

Al-Qaradhawi (2001) explains the fundamental bedrock of Islamic entrepreneurship is driven by the economic philosophy where business is based on Rabbani (God-oriented). It signifies the integration element between material and spiritual as connote in the foundation of Islamic moral economy (IME). Islamic moral economy is the practice of economic activity based on 'aqidah (faith) and akhlaq (ethics and morality) as the core (Mohd Nor, 2016). This unique foundation leads the economic transaction towards high conscience of societal wellbeing through the practice of tawheed (God-consciousness). Therefore, Shari'ah crowdfunding phenomenon indirectly creates the influence or relationship between the element of spirituality in Islam and entrepreneurship. The dimension of spirituality in Islam can positively influence the attitudes of entrepreneur and serve as a motivational drive for executing a business and also serve as a catalyst to increase social responsible commitment while enhancing financial performance (Adamu et al., 2013; Oukil, 2013). The dimension of spirituality is considered equivalent with the purification of the heart (tazkiyyah) that drives for personal attainment. In order to purify the heart (spiritual), one must achieve the highest Iman (belief or faith) and develop divine qualities of taqwa (piety), tawakkul (trust in Allah), qana'ah (contentment), sabr (patience), ikhlas (purity of intention) and believe in akhirah (the life hereafter). A study by Mubarak et al. (2014) identified that there are five main themes related to the characteristics and spirituality practice among the successful businessmen; believing the greatness of Allah, tawakkul (trusting in God's plan), morality, practice, and qana'ah (contentment). This is the criteria of a homo Islamicus which is the taba'aya individual (virtuous man) that is the opposite of homo economicus (Asutay, 2007 whom supports capitalism. Distinguishing from the classical homo economicus, a homo Islamicus imbues the human-centric perspectives inculcating the essence of spiritual accountability as the bedrock of IME (Asutay, 2007; Mohd Nor et al., 2016). Hence, Muslim business activity should strive to meet Shari'ah goals.

For entrepreneurial enhancement in Islamic countries, Asutay and Marzban (2015), address the current issue lacking in entrepreneurial, cultural and religious factor. In order to ensure fair distribution among capital providers in the case of liquidation as well as to overcome the Shari'ah concern regarding preference shares, the framework suggested to employ for start-ups structured contracts should be based on both, equity financing such as Musharakah (capital venture) and interest-free loans. Therefore, all Shari'ah crowdfunding types or model should fit into these norms and would need to be adapted to be considered as Shari'ah compliant crowdfunding (Wahjono et al., 2015; Taha \& Macias 2014). In addition, Achsien et al. (2016) stated that Shariah and crowdfunding have a similar goal and philosophical foundation that contributes to social and economic impact. Meanwhile, Lehner 
(2013) promote crowdfunding in a social entrepreneurship context which extends contribution towards socioeconomic development. The aspiration is similar to Shari'ah crowdfunding.

Most researchers agree that there are basically four different types of crowdfunding that could be categorized into community-based crowdfunding and investment-based crowdfunding. The donation-based and reward-based crowdfunding are categorized in the community-based crowdfunding, while equity-based, and lending or debt-based are investment-based crowdfunding (Hemer, 2011; De Buysere, 2012; Massolution, 2013, 2015; Kuti \& Madarasz, 2014; Asutay \& Marzban, 2015). Crowdfunding based on donation is when a donor contract without expecting any compensation. Meanwhile, crowdfunding based on reward is a purchase contract for some type of product or service. Lending-based crowdfunding or sometimes referred to as peer-to-peer (P2P) lending involves credit contract, where credit is being repaid with interest. Finally, in equity-based crowdfunding, it is a shareholding contract, equity-like instruments or revenue sharing in the project or business (De Buysere, 2012).

The nature of the financial transaction of crowdfunding is slightly different from the mainstream financial institutions. The operation of a crowdfunding includes three major players, whom are (i) the fundraiser, (ii) the investors and (iii) crowdfunding platform. The fundraiser are the project initiator or venture that in need of financial assistance to achieve their goal. In doing so, the fundraiser will pitch their project or business ideas to the investors. The investors or funders are usually the community that has interest in the project or business. As the nature of crowdfunding is pooling small amount of funds from multiple investors that agrees to join-in the project. The motivation for investors to participate in crowdfunding initiatives varies from social participation to monetary return from investment (Ordanini et al., 2011). Lastly, the most important aspect is the crowdfunding platform that becomes the rendezvous between the fundraiser and the investor. This platform is an online based meeting point that provides information and facilitate the crowdfunding process (Shofiyyah et al., 2019; Mohd Thas Thaker et al., 2018). According to Ordanini et al. (2011), crowdfunding participants are interested to use crowdfunding platforms as they are attracted to innovative behavior and the context of social networking. On another note, a Shari'ah crowdfunding must not only be attracted to the objective of project or innovative platforms used but to ensure that is according to Shari'ah, hence the importance of Shari'ah assurance that will boost confidence of the investors.

\section{Shari'ah assurance}

With respect to development and smoothness of Islamic crowdfunding practices, Wahjono et al. (2015) highlight the uniqueness and important actor in Shari'ah crowdfunding other than project initiator, platform and funder, namely Shari'ah Supervisory Board or Shari'ah Advisors. This research supported by Hassan (2015), which state the role of Shari'ah advisor is important in order to derive solutions for any Shari'ah related issues in Shari'ah crowdfunding such as Shari ah-compliant monitoring issue, equity structure, repurchase price of equity, moral hazard issue and other operational issues. Biancone and Secinaro (2016) also introduce the existence of Shari'ah board, whom could monitor the investment in every phase, provides specific Shari'ah screening and legal formalities as among some aspect that could turn equity crowdfunding in Italy to Shari'ah compliance model. Whilst Abdullah (2016) discuss Islamic crowdfunding on Shari'ah governance aspect with special reference made to the Malaysian regulatory framework to ensure crowdfunding activities to be run on the basis of Shari'ah principles. 
Shari'ah crowdfunding platform to utilize religious institution network as the platform gives ability to donate through a more trusted and secured channel, thus it can improve charity globally. This is supported by a study on waqf crowdfunding, where there is a positive impact on crowdfunders behavioral intention in using the crowdfunding-waqf model because of easy usage and usefulness of the model (Mohd Thas Thaker et al., 2018). These are another aspects that creates trust.

Trust

Trust is a human value that puts confidence in the integrity, reliability and fairness of an individual or institution (Morgan \& Hunt, 1994). According to Luhman (1979), trust is a cognitive and social device that can reduce complexity enabling people to cope with the different levels of uncertainty and risk. Trust influence the social and economic surrounding in the society. Kang et al. (2016) differentiate trust according to calculus trust and relationship trust. Calculus trust is articulated as a trust from the head that can easily be misguided according to the outcome received. Nonetheless, the relationship trust is a central trust from the heart, which has a stronger inner belief due to repeated interaction between one another. Trust is important in social interaction especially in the initial phase of a relationship or to maintain an existing relationship which would lead to reputation. Trust become an important issue when related to technology such as online since social cues are lacking to identify specific risk.

In the business scenario, trust is a valuable element between the seller and the buyer which is also relevant to crowdfunding. A funder must have trust in the projects offered by the fundraiser. This is supported by a study conducted in reward-based crowdfunding which reveals that the rich-media interaction between project owner (fundraiser) and funder built trust among them leading towards increase in sponsorship, emotional bonds and social identifications (Zheng et al., 2016). There are also studies on religion and trust in consumerism that influences the consumer's behavior especially on material, intolerance, ethics and risk aversion (Agarwala et al., 2018). According to Minton (2018), a highly religious consumer tends to have higher brand trust despite of the advertisement of the products. This experience is relevant to Muslims as trusting the halal brand and Shari'ah certifications.

According to Islam, trust is an important akhlaq (Islamic ethics) governed as a social relationship portraying a value of being responsible towards every stakeholders and holds truth of the principle (Beekun \& Badawi, 1999). The value of trust, educates a person to acknowledge God (taqwa) and thus preserve the soul from betraying what is entrusted. The prescription of Al-Qur'an and hadith is the words of God, a revelation that provide divine knowledge of truth. In order to understand and appreciate the truth, it is acquired through rational wisdom (Abuznaid, 2009). As prescribed in the Qur'an, every trust will be questioned in the day of Judgement.

"O ye that believe! Betray not the trust of Allah and the Messenger, nor misappropriate knowingly things entrusted to you." (Al-Anfal, 8:27).

Islam proclaim trust as a virtue that builds the character of the society. This is supported by a hadith, "The truthful and trustworthy businessman will be in the company of prophets, saints and martyrs on the Day of Judgement" (Darimi \& Tarmidhi).

The hadith elaborates the importance of being truthful and trustworthy in every sales contract as it portrays the Islamic image of good governance. It is a medium of da'wah (invitation to learn Islam) to educate the society. Besides, it is also a reminder to ensure 
unethical conducts such as fraud, embezzlement, misrepresentation and etc. in business to be avoided as it diminished the morality and dignity.

Although there are many advantage of crowdfunding, there are always concern related to behavior and the usage of system in the process of crowdfunding. Among the concern are related to human behavior which are moral hazard and information asymmetry. This includes risk of fraud and misleading advertising or information (Belleflamme et al., 2013, 2014).

\section{Trust: Funding motivation for Shari'ah-based crowdfunding}

This paper will attempt to discuss the value of trust from three dimension which are cognitive (calculus), affective (relationship) and also trust through religious belief - religiosity (Islam). In measuring trust, this study will look into three avenues related to crowdfunding: fundraiser-related, project-related and platform-related factors. The proposed research framework is as illustrated in table 1.

The study conducted by Kang et al. (2016) discussed trust only from the perspectives of calculus and relationship. Trust from an Islamic perspectives brings out a different paradigm that locates the relation between man and God (hablun min Allah) and; man and man (hablun min annas) (Abuznaid, 2009). The vertical and horizontal relationship depicts the essence of establishing good to all mankind by acknowledging and fearing God. Table 1 summarizes that Islam encourage trust in many aspects to promote peace and harmony.

Table 1. Trust in Shari'ah crowdfunding

\begin{tabular}{|c|c|c|c|}
\hline \multirow{2}{*}{ Fundraiser-related features } & Calculus trust & Relationship trust & Islam \\
\hline & & & \\
\hline Value congruence & $\nabla$ & $\nabla$ & $\nabla$ \\
\hline Social interaction & & $\nabla$ & $\nabla$ \\
\hline \multicolumn{4}{|l|}{ Platform-related features } \\
\hline Perceived accreditations & $\nabla$ & & \\
\hline Structural assurance & $\nabla$ & $\nabla$ & \\
\hline Third-party assurance & $\nabla$ & $\nabla$ & $\nabla$ \\
\hline \multicolumn{4}{|l|}{ Project-related features } \\
\hline Network externalities & $\nabla$ & $\nabla$ & $\nabla$ \\
\hline Perceived informativeness & $\nabla$ & $\nabla$ & $\nabla$ \\
\hline
\end{tabular}

\section{Fundraiser-related features}

The motivation to fund a project are usually related to value congruence between the fundraiser and funders especially when fundraiser is transparent and genuine about the project. This creates a calculus trust as knowledge of the project is acquired in depth (Burke et al., 2007). Reputation is also built from trust whenever projects are accomplished and funder received positive experience (Cheshire et al., 2010). This is in line with the Islamic spirit in fulfilling promises which is virtues that is prescribed in the Qur'an.

$$
\text { "O you who have believed, fulfill [all] contracts...” (Al-Maidah, 5:1) }
$$

It is important to fulfil contracts as promised to avoid any risks related to the transactions. Breach in contracts may resulting towards various damages. 
Another features that contributes to the willingness to fund a project is social interaction. The crowdfunding platform is the best medium for social interaction between fundraiser and funder to exchange information hence frequent communication leads to relationship trust (Xu et al., 2016; Zheng et al., 2016). According to Shah Alam et al. (2016), word-of-mouth is a significant factor that influence the society and builds the value of trust in sharing information online. Exchanging information is important in Islam especially in business transaction as the Prophet mentioned in the Hadith.

"Whosoever sells a defective product without disclosing its defect to the purchaser, shall earn the permanent anger of Almighty Allah and the angels continuously curse such a person" (Ibn Madja).

Through explicit exchange of information, this may reduce several risk related to information asymmetry and moral hazard. This immoral behaviour in business will lead to tarnishing the trust between both parties.

\section{Platform-related features}

Among the most important aspect to capture the interest of the funder is through the perceived project accreditation. According to Pavlou (2002), perceived accreditation happen when fundraiser provides a verification of the capital and also communicate the expected performance of the project to gain trust. This value only affects calculus trust as it requires good knowledge to be disseminate to funders. Shekra, a Shari'ah-compliant crowdfunding platform in Egypt instill quality, ethical and social responsibility as the core value to promote the Islamic components in gaining faith of the investor (Alonso, 2015).

Although technology has become part of our lives, not everyone succumbs to the new approach promoted by FinTech. The concern on technology will be the structural assurance. People needs to have faith on the technological structures such as regulation, security, transparency, resilient and many more (Bock et al., 2012; Shah Alam et al., 2016). Calculus and relationship trust affects the intention of funder as it relates to knowledge and also the bonding of the funder and fundraiser.

Third-party assurance refers to the guarantee of crowdfunding projects by a trusted certifying institutions or body (Kim, et. al, 2008) such as bank, consumer union, technology company, Shari'ah supervisory board. The presence of third-party may reduce moral hazard and information asymmetries related risk which would lead to both trust, calculus and relationship trust and also enhance the funder's faith. In the case of Shari'ah crowdfunding, the presence of Shari'ah board or Shari'ah advisor is important to screen each projects according to the objective of Shari'ah (Lutfi \& Ismail, 2016) which will lead to trust and loyalty. Through a good Shari'ah governance, it would lead to good image in the long run.

\section{Project-related features}

Crowdfunders have the tendency to fund projects that is popular among their social circles. This is called network externality (Pae \& Hyun, 2002) which would reduce uncertainty and fraud as the number of funder increases especially when funders are family and friends (Hsu $\& \mathrm{Lu}, 2004)$. The network externalities affect both calculus trust and also relationship trust. The former leads the funder to take precautions on risk stipulated with the project (Fang et al., 2009) while the latter creates a strong and positive expectation to invest in the project (See-To \& Ho, 2014). Islam encourage Ukhuwwah (unity and brotherhood) which is one of 
the important axiom in Islamic moral economy to ensure a harmony society (Mohd Nor et al., 2016). The social network creates bonding that encourage economic transactions.

The problem of asymmetry information could be avoided when all necessary information of the project reaches the funder (Kim et al., 2008). Perceived informativeness is an important criterion that leads to trust (Littlewood et al., 1995). A higher level of knowledge with accurate and current information, the higher likelihood for funder to belief and willing to invest ( $\mathrm{Li}$ et al., 2015). Both trust, calculus and relationship is said to have impact on the level of perceived informativeness. In business transaction, Islam promotes transparency for consumer protection and also loyalty.

\section{Conclusion}

Initiating a Shari'ah crowdfunding project would be exciting specially to provide for Muslim developmental needs. However, the issue of trust has become a concern, deterring funders from investing through online platform. Traditionally, Muslims prefers to crowdfund in mosques and schools where trust is established from religious belief, good relationship and knowledge of the individual or institution. This study attempts to look into the value of trust in Shariah crowdfunding. This study examine the value of trust from the perspective of calculus and relationship trust. Apart from these two criteria of trust, another criteria to be added is the religious aspect as faith contributes to trust as well. The fact that Shari'ah crowdfunding adheres to the Shari'ah law provides an extra credit to stakeholders as it builds trust. In addition, to strengthen this value of trust among investors, Shari'ah crowdfunding platforms needs to provide assurance on the legality of Shari'ah projects conducted. The Shari'ah assurance is importance to ensure good governance and therefore, here is a need to hire Shari'ah advisor or form Shari'ah board to increase trust from investor.

\section{Acknowledgement}

In completion of this study, appreciation is given to Universiti Kebangsaan Malaysia for providing research grant GGP-2017-071.

\section{Reference}

Abdullah, A. (2016) Crowdfunding as an Emerging Fundraising Tool: With Special Reference to the Malaysian Regulatory Framework. Islam and Civilisational Renewal (ICR), 7(1), 98-119.

Abuznaid, S. (2009), Business ethics in Islam: the glaring gap in practice. International Journal of Islamic and Middle Eastern Finance and Management, 2(4), 278-288.

Achsien, I. H., \& Purnamasari, D.L. (2016) Islamic crowd-funding as the next financial innovation in islamic finance: Potential and anticipated regulation in Indonesia. European Journal of Islamic Finance, 5, 1-10.

Adamu, I.M., Zulkarnain, K., \& Osman-Gani, A.M. (2013). Entrepreneurial motivation, performance and commitment to social responsibility: Toward future research. International Journal of Entrepreneurship and Small Business, 18(2), 194-210.

Agarwala, R., Mishra, P., \& Singh, R. (2018). Religiosity and consumer behavior: A summarizing review. Journal of Management, Spirituality \& Religion, 1-23.

Al-Qaradawi, Y. (2001) Min Fiqh al-Dawla fi al-Islam. Cairo and Beirut: Dar al-Shuruq. 
Alonso, I.M. (2015). Crowdfunding in Islamic finance and microfinance: A case study of Egypt in developing inclusive sustainable economic and financial systems: access to finance and human development - Essays on Zakah, Awqaf and Microfinance, Qatar Foundation Journal, Doha, Qatar.

Asutay, M. (2007). Conceptualisation of the second best solution in overcoming the social failure of Islamic finance: Examining the overpowering of homoislamicus by homoeconomicu. IIUM Journal of Economics and Management, 15(2), 167-195.

Asutay, M., \& Marzban, S. (2015). Alternative ways of developing the GCC Islamic funds industry: entrepreneurial development. In M. Asutay, \& A. Turkistani, (Ed). Islamic finance: Political economy perspectives, Berlin: Gerlach.

Beekun, R., \& Badawi, J. (1999). The leadership process in Islam. Proteus-Shippensburg, 16, 33-38.

Belleflamme, P., Lambert, T., \& Schwienbacher, A. (2013). Individual crowdfunding practices. Venture Capital, 15(4), 313-333.

Belleflamme, P., Lambert, T., \& Schwienbacher, A. (2014). Crowdfunding: Tapping the right crowd. Journal of Business Venturing, 29(5), 585-609.

Biancone, P.P., \& Secinaro, S. (2016). The equity crowdfunding Italy: A model sharia compliant. European Journal of Islamic Finance, 5, 1-10.

Bock, G.W., Lee, J., Kuan, H.H., \& Kim, J.H. (2012). The progression of online trust in the multichannel retailer context and the role of product uncertainty. Decision Support Systems, 53(1), 97-107.

Burke, C.S., Sims, D.E., Lazzara, E.H., \& Salas, E. (2007). Trust in leadership: a multi-level review and integration. The Leadership Quarterly, 18(6), 606-632.

Cheshire, C., Antin, J., Cook, K.S., \& Churchill, E. (2010). General and familiar trust in websites. Knowledge, Technology \& Policy, 23, 311-331. https://doi.org/10.1007/s12130-010-9116-6.

De Buysere, K., Gajda,O., Kleverlaan, R., Marom, D., \& Klaes, M. (2012). A framework for European crowdfunding, European Crowdfunding Network.

Fang, J., Shao, P., \& Lan, G. (2009), Effects of innovativeness and trust on web survey participation. Computers in Human Behavior, 25(1), 144-152.

Gerber, M.E., \& Hui, J. (2013). Crowdfunding: Motivations and deterrents for participation. Journal ACM Transaction on Computer-Human Interaction (TOCHI), 20(6), 1-34.

Gierczak, M.M., Bretschneider, U., Haas, P., Blohm, I., \& Leimeister, J.M. (2016). Crowdfunding: Outlining the new era of fundraising. In: D., Brüntje, \& O., Gajda. (eds). Crowdfunding in Europe. FGF Studies in Small Business and Entrepreneurship. Springer.

Hassan, A. (2015). Shari'ah Compliance under Islamic Financial Services Acts 2013 and its challenges (November). Muzakarah Penasihat Syariah Kewangan Islam Kali Ke-9. Kuala Lumpur Islamic Finance Forum 2014.

Hemer, J. (2011). A Snapshot on Crowdfunding. Fraunhofer Institute for Systems and Innovation Research, Karlsruhe.

Hsu, C.L., \& Lu, H.P. (2004). Why do people play on-line games? An extended TAM with social influences and flow experience. Information \& Management, 41(4), 853-868.

IFSB. (2017). Islamic Financial Services Industry Stability Report 2017. Bank Negara Malaysia, Kuala Lumpur.

Kang, M., Gao, Y., Wang, T., \& Zheng, H. (2016). Understanding the determinants of funders' investment intentions on crowdfunding platforms: A trust-based perspective. Industrial Management \& Data Systems, 116(8), 1800-1819. 
Kim, D.J., Ferrin, D.L., \& Rao, H.R. (2008). A trust-based consumer decision-making model in electronic commerce: The role of trust, perceived risk, and their antecedents. Decision Support Systems, 44(2), 544-564.

Kuti, M., \& Madarasz, G. (2014). Crowdfunding. Public Finance Quarterly, 59(3), 355-366.

Lehner, O.M. (2013). Crowdfunding social ventures: A model and research agenda. Routledge Venture Capital Journal, 15(3), 1369-1066.

Li, Y., Li, G., Feng, T., \& Chong, A. (2015). Effects of suppliers' trust and commitment on customer involvement. Industrial Management \& Data Systems, 115(6), 1041-1066.

Littlewood, B., Neil, M., \& Ostrolenk, G. (1995). The role of models in managing the uncertainty of software-intensive systems. Reliability Engineering \& System Safety, 50(1), 87-95.

Luhman, N. (1979). Trust: A mechanism for the reduction of social complexity. In N., Luhman. (1979). Trust and power: Two works, Chichester: John Wiley and Sons.

Lutfi, M.A., \& Ismail, M.A. (2016). Sadaqah-based crowdfunding model for microfinancing and health care. Journal of Muamalat and Islamic Finance Research (JMIFR), 13(2), 31-51.

Marzban, S., Asutay, M., \& Boseli, A. (2014) Shariah-compliant crowd funding: An efficient framework for entrepreneurship development in Islamic countries. Eleventh Harvard University Forum on Islamic Finance. 24-27 April 2014, Cambridge MA.

Massolution, C.F. (2015). Crowdfunding Industry Report, 2015.

Massolution, C.F. (2013). Crowdfunding Industry Report, 2013.

Minton, E.A. (2018). Believing is buying: religiosity, advertising skepticism, and corporate trust. Journal of Management, Spirituality \& Religion, 1-22.

Mohd Nor, S., Abdul Rahim, R., \& Che Senik, Z. (2016). The potentials of internalising social banking among the Malaysian Islamic banks. Environment, Development and Sustainability, 18(2), 347-372.

Mohd Thas Thaker, M.A., Mohd Thas Thaker, H., \& Allah Pitchay, A. (2018). Modeling crowdfunders' behavioral intention to adopt the Crowdfunding-Waqf Model (CWM) in Malaysia: The theory of the Technology Acceptance Model. International Journal of Islamic and Middle Eastern Finance and Management, 11(2), 231-249.

Morgan, R.M., \& Hunt, S.D. (1994). The Commitment-Trust Theory of relationship marketing. Journal of Marketing, 58(3), 20-38.

Mubarak, M.Z., Abd Rahman, A., \& Yaacob, M.R. (2014). Spirituality in Islamic entrepreneurship: Motivation and achievements of successful entrepreneurs in Kelantan. Journal of Techno Social, 6 (2), 27 -36.

Ordanini, A., Miceli, L., Pizzetti, M., \& Parasuraman, A. (2011). Crowdfunding: Transforming customers into investors through innovative service platforms. Journal of Service Management, 22(4), 443-470.

Oukil, M.S. (2013). Entrepreneurship and entrepreneurs in an Islamic context. Journal of Islamic and Human Advanced Research, 3(3), 111-131.

Pae, J.H., \& Hyun, J.S. (2002). The impact of technology advancement strategies on consumers' patronage decisions. Journal of Product Innovation Management, 19(5), 375-383.

Pavlou, P.A. (2002), Institution-based trust in interorganizational exchange relationships: The role of online B2B marketplaces on trust formation. Journal of Strategic Information Systems, 11(3/4), 215-243.

Schwienbacher, A., \& Larralde, B. (2010). Crowdfunding of Small Entrepreneurial Ventures. Handbook of Entrepreneurial Finance, Oxford University Press, Oxford. 
See-To, E.W.K., \& Ho, K.K.W. (2014), Value co-creation and purchase intention in social network sites: The role of electronic word-of-mouth and trust $-\mathrm{a}$ theoretical analysis. Computers In Human Behavior, 31(2), 182-189.

Shah Alam, S., Ahmad, M., Ali Khatibi, A., Nilufar Ahsan, M. (2016). Factors affecting trust in publishing personal information in online social network: an empirical study of Malaysia's Klang Valley users. Geografia-Malaysian Journal of Society and Space, 12(2), 132-143.

Shofiyyah, M., Abdul-Rahman, A., \& Mohd Nor, S. (2019). Awareness and motivation in crowdfunding for Islamic banking and finance research. Global Journal of AlThaqafah, special issue, 7-18.

Taha, T., \& Macias, I. (2014). Crowdfunding and Islamic finance: A good match? In: F.M., Atbani, \& C., Trullols. (eds) Social Impact Finance. IE Business Publishing. Palgrave Macmillan, London

Wahjono, S.I. (2015). Islamic crowdfunding: Alternative funding solution. Paper presented at 1st World Islamic Social Science Congress (WISSC 2015), Putrajaya, Malaysia, 1-2 December 2015.

World Bank. (2013). Crowdfunding's potential for the developing world. The World Bank, Washington.

Xu, B., Zheng, H., Xu, Y., \& Wang, T. (2016). Configurational paths to sponsor satisfaction in crowdfunding. Journal of Business Research, 69(2), 915-927.

Zheng, H., Hung, J., Qi, Z., \& Xu, B. (2016). The role of trust management in reward-based crowdfunding. Online Information Review, 40(1), 97-118. 